\title{
The Virtues of Dialogue between Academics and Businessmen
}

\author{
Lise Arena (University of Nice Sophia-Antipolis, CNRS, France) \& Leonard \\ Minkes (Emeritus Professor, University of Birmingham, UK)
}

Correspondence:

Lise Arena-lise.arena@unice.fr

Campus St Jean d'Angély, 24 Avenue des Diables Bleus, 06357 NICE (FRANCE)

Lise ARENA is an Associate Professor at the CNRS-University of Nice Sophia-

Antipolis Research Institute GREDEG (FRANCE) where she obtained her Ph.D. in Management in 2009. She also holds a D.Phil. in Modern History (2011) from the University of Oxford. Her major research interests are: the history of management and the role of digital artefacts and practices in social organization. Her recent work in history of management has been published in Entreprises et Histoires and History of Economic Ideas.

Leonard MINKES is Emeritus Professor of Business Organisation in the University of Birmingham. Educated at Balliol College, Oxford, he has lectured in universities, management centres in industry, and other organisations, and has acted as a consultant on business topics and management training in Britain and overseas. He also spent part of his career in the Economic Commission for Europe of the United Nations. From 1974-1980, he was a non-executive member of the Midlands Postal Board in Britain and from 1975-1983, he served on the Council of the Birmingham Chamber of Industry and Commerce. He has published widely in books and journals, especially in the areas of business behaviour and strategic management. 
A Forgotten British Method? The Rise and Fall of Dialogue between Academics and Businessmen

\begin{abstract}
This article aims to understand the process of production of knowledge in the field of business organization and in problems of administration. We argue that the acquisition of this type of knowledge is greatly assisted by the developments of dialogue between academics and industrialists. We look at a method which has been applied in England during the period late 1940s to early 1970s in three academic seminars: The Seminar in Problems of Administration at the LSE (1947-1972); The Industrial Seminar at Birmingham University (late 1950s-1972); and the B.Phil. Seminar in Economics of Industry at the University of Oxford (1957-1974). By the mid-1970s, these three seminars ceased to exist and left room to the rapid development of management studies, on the one hand, and to the formalization of industrial economics (game theory), on the other hand.
\end{abstract}

Keywords: Management Education, Business Organization, LSE, University of Oxford, University of Birmingham, Empirical realism, Seminar method

\title{
Introduction
}

Links between universities and businesses have been studied from different perspectives, such as universities-industries innovations and research joint-ventures, commercialisation of knowledge in universities and academic patenting, the status of case-study methods and the role of alumni networks in the dynamics of universities. This research contributes to the understanding of these links in the context of early attempts to generate dialogue between academics and businessmen, in a process of theory-building. In particular, it aims to understand the process of production of knowledge in the field of business organization and economics of the firm between 1940s and 1970s in the UK. The particular feature of this work is that the acquisition of this type of knowledge is greatly assisted by the developments of dialogue between academics and industrialists, which eased the production of working knowledge in business organization and problems of administration. 
This key idea is derived from the historical analysis of three early seminars in which this dialog took place. In particular, we look at a method which had been applied in England during the period late 1940s to early 1970s in the following academic seminars: The Seminar in Problems of Administration at the LSE set up and ran by Ronald Edwards (1947-1972); The Industrial Seminar at Birmingham University set up by Leonard Minkes with Philip Sargant Florence as Chairman (late 1950s-1972); and the B.Phil. Seminar in Economics of Industry at the University of Oxford set up by Philip W. Andrews and co-chaired with Elizabeth Brunner (1957-1974). By the mid1970s, these three seminars ceased to exist and left room to other approaches and developments in the studies of firms and industries. To a large extent, although of different nature, these three seminars reflected a shared effort to provide an empirical approach to the understanding of firms and industries with a particular emphasis on industrial structure, business behaviour and decision-making. This form of empiricism did not only consist of collecting facts but, rather, showed the importance of exchange and dialogues between academics and industrialists which led to a better understanding of firms' decisions, behaviour and dynamics as well as industrial policy. This desire to provide a new form of economic analysis which was meant to fit the facts better than earlier theories echoes the diffusion of some key ideas and new approaches in the discipline: analysis of cost accounting at the LSE, consideration of bounded rationality at Birmingham and oligopoly theory and empirical cost functions in Oxford. The common denominator between these initiatives was to provide students with working knowledge, considered to be mainly absent from previous theories of the firm and of industries. More implicitly, it could be seen as a critique of marginal cost as well as rational choice theories. 
In line with its main objective, this article naturally falls into three parts. The first part contextualizes the three seminars in the broader tendency of empiricism in British economics during the 1930s-1940s period. The second part of the article offers a detailed analysis of the rise and fall (1947-1974) of the three seminars based on archival sources and on one of the author's main recollections (especially in relation to the seminar in Birmingham). The third and last part of this work discusses the causes of these trends and contextualise this method in a more international landscape. The emergence of new problems in the course of development of these seminars as well as more individual reasons concerned with the chairmen's own positions and careers are discussed as explanations of their interruption.

\section{Empiricism and British Economics (1930s-1940s)}

There is nothing new nor essentially controversial in the idea of empiricism in the study of economics of the firm or of economic behaviour as a whole. Thus, Adam Smith was deeply concerned with the acquisition of 'real' data; so were other thinkers in the early institutionalisation of political economy (cf. Cary (1695) and Petty (1662)). It was as far back as the 1830s that the Manchester Statistical Society was founded with the explicit intention of advancing empirical knowledge in both the economic and social spheres. Alfred Marshall was certainly one of the pioneer economists who initiated the first efforts of empirical work conducted in the domain of economics of the firm, of industries and business organization.

\section{Alfred Marshall's legacy}

Alfred Marshall did attach importance to applied study of economic phenomena, as exemplified in the introduction of the new Tripos in Economics at the beginning of the $20^{\text {th }}$ century. Marshall justified this new undergraduate programme as a preparation for 
students to enter business life and his aim was to develop more than just a technical education in the discipline. Indeed, he remarked:

"What is desired is not technical instruction, but an education of a high type, which shall have the additional advantage of preparing the student to take, without unreasonable delay, a responsible place in business or in public life." (Cambridge special committee of the Senate, 6th June 1903, in Marshall, 1903, p. 3).

Undeniably, businessmen's opinions did matter in Marshall's attitude. The new Tripos was motivated by Marshall's fear of seeing the sons of English businessmen sent to newer Universities which would potentially offer them a more practical education. Marshall's position towards dialogue with businessmen might echo his stay at University College, Bristol, during the period 1877-1881. There, Alfred and Mary Marshall, recently married, were teaching students who were less academic than those in Cambridge and had consequently adjusted the content of their lectures ${ }^{1}$. Yet, this experience brought Marshall "into the public eye and to a first-hand acquaintance with the wider world of affairs" (Whitaker, 1972: 1). On his return to Cambridge, in his Introductory Lecture given in the Senate House in 1885, Marshall addressed the needs for Universities to be "more in sympathy with business":

“[...] if more University men looked upon their life here as preparing them for the higher posts of business, what a change they might make in the tone of business! Just and noble sentiments might be introduced into counting-house and factory and workshop, without the dangers which weak benevolence runs of turning sentiment into sentimentality, of courting ruin and increasing the common prejudice that a pleasant looking house of business is likely to be financially unsound. If our

\footnotetext{
${ }^{1}$ In Marshall's Outlines of Courses of Lectures on Political Economy Given at University College, Bristol, one can read "The lectures will be adapted to the requirements of those who have some acquaintance with economic science, or with the practical conduct of business" (reproduced in Whitaker, 1972: 44).
} 
Universities were more in sympathy with business, charitable England would not have left to other countries so much of the work of pioneering the way towards making factory life pleasant and beautiful." (Marshall, 1885, pp. 55-56).

Marshall's economics was developed as a combination between theoretical elements and empirical facts. Although this early impulsion made by Marshall, empirical work did not remain at the heart of the Cambridge School of Economics. Marshall's legacy was soon to become encapsulated within a series of famous debates in the 1930s, which mainly dealt with theoretical foundations of costs and economic returns and also led to the publication of the Economics of Imperfect Competition by Joan Robinson. This Cambridge trend led to a more general critique in the country that claimed for the increasing need of empirical approaches in economics.

\section{Towards empirical approaches to the firm and industry in the UK (1930s-1940s)}

The 1920s-30s debate on the Cambridge Cost Controversies questioned the theoretical meaning of Marshall's work. Through the publication of a series of articles in the Economic Journal, a series of challenges were addressed to the evolving 'Marshallian' orthodoxy and eventually led to the concept of imperfect competition. The starting point is the attack against the technical developments of Marshall by Clapham in 1922. In his article, Clapham expressed a general doubt, concerning the complexity of Marshall's theory, which tried to combine decreasing returns in an individual firm (in order to maintain the hypothesis of perfect competition) with increasing returns at the industrial level. He especially disagreed with Marshall's concept of increasing returns, which he considered as an 'empty box'. Thus, in opposition to a classification of industries on the basis of variable returns, Clapham suggested a more historical, descriptive approach, in order to get closer to 'things of life' (Clapham, 1922: 305). In his reply to Clapham's critique, Pigou (1922) accused Clapham of failing to distinguish between 'realism' and 
'practical usefulness'. Two years later, Pigou was forced to defend the existing orthodoxy (Pigou, Robertson, 1924). Robertson's criticism of Pigou's reply to Clapham held that Pigou's treatment of the Laws of Return in the Economics of Welfare (1920) not only rendered the filling of the empty boxes unnecessarily difficult but also positively misleading and dangerous, if they were to be used as a guide for policy implementation. To a large extent, these controversies on costs were therefore the first attempts to assess the importance of industrial facts, 'things of life' and to evaluate the realism and practical usefulness of economic theory. Yet, all the debates were centred on the theoretical foundations of costs and left very little room to any dialogue with businessmen in Cambridge.

In the newly-established University of Birmingham, the role of William James Ashley was more significant in the development of empiricism in economics. Ashley took the first Chair of Commerce in 1902 when he oversaw the B.Com. degree as a qualification for students who would be entering on business careers. In line with Ashley, Philip Sargant Florence, who was Professor of Commerce at Birmingham (1929-1955) and who had attended Marshall's lectures at Cambridge, thought that the logic of industrial organization could only be established if there was a basis in the facts of industrial behaviour ${ }^{2}$.

While the inter-war period in Cambridge was animated by theoretical debates which have been later qualified as the years of High Theory, Oxford economists

\footnotetext{
${ }^{2}$ Leonard Minkes' recollection is that he had little patience with the drawing of long-run envelope curves, showing economics of scale: yet he was a pioneer in recognizing the existence of indivisibilities in factors of production as source of such economies. Oddly, however, he saw no limits to scale if appropriate management was achieved.
} 
gradually developed a more empirical approach to economics, also in response to developments on imperfect competition. This trend was largely supported by two institutional developments: The Oxford Economists Research Group (OERG) as well as the Oxford Institute of Statistics. The Oxford Institute of Statistics was formally established on 22 October 1935 under the direction of the Social Studies Research Committee, with J. Marschak appointed as its director ${ }^{3}$. The OERG was created in 1936 and as a part of the Oxford Institute of Statistics. Initially led by Sir Hubert Henderson (sole Professor of Economics in Oxford), the meetings of the OERG's studies basically consisted of sets of research projects which took about eighteenth months and which were based upon questionnaires. These questionnaires were sent in advance and then based on after-dinner interviews with businessmen who were invited to come to Oxford to dine and spare an evening answering the members' questions. They had intensive discussion and questioning took place from about $8.30 \mathrm{pm}$ until the small hours of the morning. All the businessmen were promised complete confidentiality. A record was kept of what was said after each meeting, before being sent back to the guest, allowing him to alter his comments. A copy was then given to each of the members of the Group on condition that it was regarded as strictly confidential to them personally. This procedure to study firms in economics was perceived as a completely new methodology at the time, and broke with traditional deductive methods ${ }^{4}$.

\footnotetext{
${ }^{3}$ For a further detailed account, see Chester, 1986: 54-55 and Lee and Young, 1993: 120-125.

${ }^{4}$ Interestingly, this research practice was also used by politics fellows during the same period. This is evidenced in The History of the University of Oxford: The Twentieth Century. In particular, Harrison notes: “In the 1930s, while Henderson' Economists Research Group was entertaining visiting businessmen, politics tutors were entertaining visiting nonacademic speakers in their Public Administration Group" (Harrison, 1994(b): 388-389).
} 
What is particular to this article, therefore, is not the idea that the facts matter: rather it is the idea of dialogue. We observe that the Seminar process has the capacity to focus attention on economic phenomena, such as costs determination and decisionmaking processes in face of the reality, which businessmen face and inhabit. It is argued that management perception is a statement about reality and that it is important, therefore, to focus on the element of managerial perception of industrial phenomena.

\section{Rise and fall of Three Seminars in Economics of Industry and in Problems of Administration (1947-1974)}

This second section of the paper hree seminars based on dialogue between academics and businessmen had been organised between the end of the 1940s and the mid-1970s in the UK. his second section describes and seeks to understand the rise and fall of these three seminars, while it inserts them in a more intellectual and institutional landscape.

This section is based on primary and secondary sources. First, the examination of the LSE seminar relies on R. Edwards' archives (including seminars papers) that are held in the LSE archives. It is also based on the publications of two books (Edwards \& Townsend, 1958; 1967) that exposed the contents and empirical material discussed in the Seminar in Problems of Administration throughout the year. Second, the Industrial Seminar (Birmingham) is remembered with the help of Leonard Minkes' own memories as well as his Inaugural Lecture at Birmingham addressed in 1972. It is also based on the publication of Minkes \& Nuttall (1985) that exposed the discussions that took place during the seminar. Last, concerning the Graduate Seminar in Economics of Industry (Oxford), the analysis results exclusively from primary sources, such as personal archives from participants to the seminar (e.g. David Stout and George Richardson), Andrews and Brunner's archives (LSE), interviews conducted with Oxford dons and graduate seminar's exam questions. 


\section{Seminar in Problems of Administration (1947-1972), London School of}

\section{Economics}

In 1919, the LSE had the second Chair of Accounting in the country (after Birmingham in 1902) and trained a new generation of economic theorists who applied their ideas to practical business problems, especially in accounting. In the 1930s, under the leadership of Professor Arnold Plant, the London School of Economics (LSE) continued to develop a tradition in accounting, commerce and business economics. Plant was an applied economist interested by industrial organization and very much concerned with empirical observations. Interestingly, this specific LSE tradition developed intellectual foundations far from the orientations taken by another research group led by Lionel Robbins which was more interested in pure economic theory and whom members were Friedrich Hayek, Knut Wicksell, John Hicks, and Nicholas Kaldor.

Early members of Plant's group were Ronald Coase (later a Nobel Laureate in Economics), George Thirlby and Ronald Edwards. After a career in professional accounting, Edwards was appointed as an assistant lecturer at the LSE in 1935 and helped developing the opportunity cost tradition, especially with his analysis of cost accounting (Edwards, 1937) and income measurement (Edwards and Black, 1938). In his Essays on Economics and Economists, Ronal Coase remembered the significance of Plant's influence and the abilities of Ronald Edwards:

\footnotetext{
"So far as I was concerned, perhaps Plant's main influence was in bringing me to see that there were many problems concerning business practices to which we had no satisfactory answer. Plant had many able students, among them [...] Ronald Edwards". (Coase R.H., 1994, Essays on Economics and Economists, p. 213)
}

Edwards' study of accounting was rooted in economic theory. His interests in industrial research, business organisation, business growth and business enterprise led him to set up an evening seminar that included businessmen, civil servants, university 
teachers and postgraduate students. Businessmen's professional background was diverse, such as in science and technology, accountancy, economics, law, marketing and personnel management. The rules were as follows: a paper (circulated to its members in advance) was prepared by an industrialist, or sometimes a civil servant, for each meeting. Based on this preliminary paper, hundreds of discussions took place until 1972 that lead to "valuable collection of industrial case material". In their 1958 book, Edwards and Townsend summed up the aim of the papers, as such:

\footnotetext{
"Many of these papers review the development and organisation of particular firms, industrial groups or other undertakings concerned with industry and trade, and are presented by company chairmen, managing directors or other senior executives" (Edwards \& Townsend, 1958, p. vi)
}

Members of the Seminar in Problems of Administration mainly used dialog with businessmen to bridge the "gap between economic theory and economic fact". In particular, Edwards' objective was to challenge "fascination of economic analysis and model-building" that had attracted a high proportion of the "ablest minds amongst economists away from empirical research". The dialog with industrialists also aimed at providing a better understanding of the "actual operations of firms and industries" before drawing any of the big issues in industrial organisation. The status of facts vis-àvis economic theory is not that clear when scrutinizing the seminar papers. On the one hand, the seminar ambitioned to discover "facts that the theories have to explain and predict", so that "economic analysis can also be the study of business activity". On the other hand, the aim was to test economic theories. In their book, Edwards and Townsend argued: "Sound economic theories are a prerequisite of useful empirical research, but they are sterile unless they are tested against the actual facts of the economy". 
Overall, the collection of data based on the seminar papers and the two books is, most of all, used to infer theory from factual observations. Theory-testing is almost absent from the analysis. And at the end, topics are so varied that there is no common theme/ theoretical background, beyond industrial organisation, unifying dialogs of businessmen.

Yet, if the uniformity in the program underlined by the LSE seminar in problems of administration is discussable, it still inspired other seminars of the same type, as shown in the two following sections.

\section{Industrial Seminar (Late 1950s-1972), Birmingham University}

Leonard Minkes arrived at Birmingham in 1954 after being a young member of academic staff at the LSE. He was motivated by the experience of the Edwards Seminar and the possibility of benefiting from the skills and reputation of Philip Sargant Florence who was approaching retirement from the Chair of Commerce to develop a seminar based on a dialog with industrialists in the Birmingham region. As highlighted in the first section of this paper, Birmingham had a long tradition in applied economics mainly based on its Faculty of Commerce created in 1902. Philip Sargant Florence who was first a Lecturer in Economics at Cambridge (1921) became the Professor of Commerce at Birmingham in 1929. His main research interests were in economics and sociology of industry and more specifically in the issues of ownership and control in large companies. Sargant Florence had developed particular interest in detailed statistical information and in the development of 'economics and human behaviour'

\footnotetext{
${ }^{5}$ More details about the academic career and the economic thought of Philip Sargant Florence could be found in Minkes (2011) and Arena (2014).
} 
To a large extent, his view of economics contrasted with the approaches developed by standard British economists in these days. He continually challenged methods used by economists, as explicitly stated in the following:

"The unaided reason of economists cannot possibly cope with the infinite possibilities of man's behaviour; economists must continually take precautions against rational assumptions by the teaching of fairy-tales, nursery rhymes, and nonsense jingles". (Sargant Florence P., 1927)

Based on the initiative of Leonard Minkes, Philip Sargant Florence became Chair of the newly formed Industrial Seminar in the late 1950s. This initiative was taken in an institutional context where management education was emerging at Birmingham. Minkes, recognising the growing interest in University management education in England, expressed an interest and willingness to build up appropriate and continuing systems with industrialists. Along with other supporters of this initiative (such as Professor Gilbert Walker), Minkes also established two other seminars: one for private, one for nationalised industries in which younger executives spent one day a week in academic study.

The Industrial Seminar consisted of an evening seminar held on ten occasions every year and attended by about 60 people (of whom $2 / 3$ from industry). The visitor from the company submitted a paper in advance (in which he described the development of his company), which was the basis for further discussion. The main issues discussed during the sessions were concerned with organisational change and process, growth of firms, strategic choice, entrepreneurship, management initiative and decision-making. The content and main discussions conducted during the seminars had been accounted in Minkes and Nuttall's book which was published almost ten years after the end of the seminar. The specificity of the dialog as a method to produce knowledge is made explicit by the authors: 
"The methodology of the book is to present case material interspersed with commentary. This material does not comprise case studies in quite the sense of the conventional workbook: it may better be described, perhaps, as case evidence. Its origin is an interesting example of the way in which ideas can be stimulated and research generated by exchange between industrialists and academics" (Minkes \& Nuttall, 1985)

Beyond providing case evidence, the objective of the seminar was more specific than the one put by Edwards at the LSE. The seminar was seen as a way to provide insights for a better understanding of "business behaviour" and "business strategy". In line with the Birmingham tradition, the dialog stimulated by the seminar aimed at showing how business strategy could emerge in the "large and complex modern corporation with its network of hierarchical and lateral forms". Much more precise than the LSE seminar framework of dialogue, the Industrial Seminar developed a detailed conceptual framework concerned with behavioural and organisational theories of the firm. In particular, the key idea was to draw "critical reality" to current theoretical considerations in decision-making analysis taken in a world in which "knowledge is incomplete, imperfect and dispersed". The reference to decision-making was of particular interest especially as to understand decisions underlying the corporate behaviour. Brian Loasby has expressed the view that, at the time, micro-economic theory has little to tell us about the nature of decision-processes in firms ${ }^{6}$. He commented that his studies of industrial location, early in his career, led him to go and talk to businessmen about their experiences of relocation - which in turn led him to realise that 'decision-making' was an important and analysable topic'

\footnotetext{
${ }^{6}$ Recent personal correspondance with Brian Loasby.

${ }^{7}$ Loasby was a research fellow at Birmingham University for several years, studying location of industry, early in his career. He attended a number of meetings of the Industrial Seminars
} 
A further point which emerged and which appeared in a number of Seminar papers, is the inseparability of strategic choice of product-market scope from creation of corporate structure. What was also taken into account was that the study of managerial decision-making was intimately associated with the study of corporate structure as well as with the behaviour of the individual executive ${ }^{8}$. That is well-exemplified in Simon's proposition that the executive in an organization looks at his decisions not only specifically, but also in relation to their organisational consequences. This interrelatedness has explicit consequences for the consideration of centralisation and decentralisation in business enterprises, as we can see in looking at some of the Seminar papers. And the empirical approach, especially in conversational dialogue, focuses attention not as the 'mental construct' as Machlup termed it, but as an organisational structure (as e.g. Tivey envisaged in his book 'The Politics of the Firm' or as Ross wrote a field of constructive conflict) ${ }^{9}$.

Yet, in this conceptual framework, there was no clear desire to make generalisations from studies of firms and their decisions but rather to favour the emergence of 'recurring themes' in one dialog after another. Put differently, the collection of data based on the seminar papers and the book was mostly used for case evidence that could enrich an initial conceptual framework (such as H. Simon's developments on decision-making for instance). In line with the Seminar in Problems of Administration, theory-testing was not ambitioned in the organization of this seminar.

- of which it is only fair to say, he has no detailed recollection, but exemplifies his growing interest in decision-making and conversation with businessmen.

${ }^{8}$ Ansoff separates strategic and administrative decisions. They are, of course, intimately associated.

${ }^{9}$ Tivey in political science, Ross in industrial relations: both attended the Birmingham seminar, as did Geoffrey Gilbert, from the Chemistry department. 
To a large extent, case evidence could also serve business history which in turn could serve the understanding of step-by-step decision-making process (including coincidences and contingencies familiar to decision-makers).

\section{Graduate Seminar in Economics of Industry (1956-1974), University of Oxford}

In Oxford, the weekly graduate (B.Phil.) seminar in the economics of industry illustrates substantial theoretical and empirical developments in empirical industrial economics during the period 1952-1968. The B.Phil. in Economics has only been introduced since the War, and it originally offered students a choice between one compulsory theoretical and one compulsory Applied Economics paper. ${ }^{10}$ Two advanced papers could then be chosen in addition to the compulsory ones, but these were mainly traditional topics, such as international trade or statistics (Brunner, 1961: 1-2). These seminars gave a new opportunity for the B.Phil students to become more specialised in the topics they were really interested in. One of the senior and most popular seminars among students was the two-year graduate seminar in Applied Economics. The first sessions of the seminar did not seem to be very attractive, and "made a very shaky start [...] with only two people apart from seniors at the first meeting" (Brunner, 1961: 3). However, the attendance rapidly grew to 12 members. It was run by Sir Hubert

\footnotetext{
${ }^{10}$ As Elizabeth Brunner rightly pointed out, 'there was no formal teaching of graduates at
} Oxford until after the War. Until 1947, if you wanted to read a higher degree you wrote a thesis and submitted it for either a B.Litt. [2 years, research report] or a D.Phil. [up to 4 years, originality and worthy of publication]. [...] After the War, it became clear that graduate work at Oxford was going to be greatly expanded. People were demanding to find some organization. [...] And Oxford introduced a new graduate degree, the B.Phil., equivalent to the B.Litt. in standing but to be taken by examination not thesis and to be taught by class instruction. B.Phil. for 2 years (exceptionally 1) primarily for Philosophy, Economics and History.' (Brunner, 1961: 2) 
Henderson, Sir Henry Clay, Frank Burchardt and Philip Andrews. The seminar used to meet every Monday at 5pm at the Oxford Institute of Statistics and covered a very wide field, not only the firm and industries but also national income, employment, and macro-economic topics ${ }^{11}$. Henderson's role in the seminar was central. When he died, Worswick took his place, which caused the seminar to be split in two parts in 1956. Balogh was in charge of the public policy/budget angle and Andrews took the economics of industries part. Each speciality became a year's course only and the seminars were both held at the same time. Andrews re-organised it as a specialised seminar in industrial economics. In a letter to one of the businessmen he invited in the early days of the seminar, he wrote:

\footnotetext{
"There was some left-wing manoeuvring in the summer which gave me a chance, much to their surprise, to convert the seminar into something much more systematic and I think offering better value." (Letter from P.W.S. Andrews to David Liston, The Metal Box Company, 10/01/1957, Andrews and Brunner's Archives, LSE library)
}

Andrews was running the seminar with Elizabeth Brunner, Eric Hargreaves, and Dr. Burchardt who was the Director of the Institute of Statistics. The sessions of this new seminar took place in Nuffield every Monday at 5pm. The entry was limited to twelve members, all graduates interested in the economics of the firm and the economics of industry. During the first term of the session, the group had no visitor and each member learnt to know others by reading literature bearing on practice in industry and discussing practical evidence on particular topics, stressing their implication for theory. For the remaining two terms of the academic year, the seminar invited visitors to

\footnotetext{
${ }^{11}$ Letter from P.W.S. Andrews to David Liston, The Metal Box Company, 10/01/1957,
} Andrews and Brunner's archives: Box 529 
enlighten the group from their own practical experience. Each session was opened by a graduate member who had to read a short paper on questions relevant to the seminar, before setting them against the background of generally accepted theory. The organisation of the sessions was very different to the other seminars of the time. As E. Brunner remarked:

\footnotetext{
"The course of other seminars is that someone reads a lengthy paper, the senior members then hold forth, and there is no real discussion. We have aimed at short papers and real discussions" (Brunner, 1961: 3)
}

The guest was first asked to give a brief description of his business and its products, to thereafter comment on the paper from the point of view of his experience, before a general discussion followed ${ }^{12}$.

The topics selected in the seminar were diverse. For example, in Michaelmas Term 1958, five main enquiries, in line with the purpose of industrial economics, were studied: 'the behaviour of costs', 'the competitive process', 'barriers to new competition', 'innovation' and 'restrictive trade practices'. In later terms, these theoretical analyses were completed by the discourse of a 'practical guest', such as: 'businessman who had marketed an innovation', 'pricing policies for different sort of products', 'businessman on deciding the scale of a plant', and 'cotton industry after giving up price fixing' (Brunner, 1961: 5). The organisation of the seminar was implemented during the first term around theoretical discussions, in order to give more sense to the scope of the questionnaires, which were sent in later.

When Andrews and Brunner left Oxford in 1968, David Stout was left in charge of the B.Phil. seminar in industrial economics and, he in turn, left Oxford in the early

\footnotetext{
${ }^{12}$ Different Oxfordshire businessmen were speaking at this seminar every week.
} 
1970s, losing touch with its organisation in 1974. Then Derek Morris became its organiser and reoriented the topics in a different direction. A closer look at the reading lists for each topic (per week) mentioned above shows that the reading list for Week 2 includes references to Berle and Means, Marris and Williamson, as contributions to the extensions of the profit maximising hypothesis, without referring at all to Hall and Hitch or to any work made by empirical approaches developed by the OERG in Oxford $^{13}$.

The use of dialog between academics and industrialists is rather different in the Oxford context than in the LSE and Birmingham seminars. It is clear from archival evidence that what Andrews had in mind was to use real facts related by businessmen to challenge deductive and normative approaches in industrial economics.

\section{Discussion}

The interpretation of the emergence, rise and fall of these three seminars is based on three types of analysis. First, we contextualise these methodological initiatives in a broader international context and show that these seminars were representative of a more general tendency towards a form of empirical realism in the 1960s. Second, we provide a more analytical explanation of the seminars in assessing the evolution of the Oxford seminar in Economics of Industries. A text analysis is used to scrutinize the content of the seminars papers and their evolution on the period. Last but not least, causes of interruption due to the emergence of new problems are exposed.

\footnotetext{
${ }^{13}$ Further details about this new orientation of the seminar could be found in section 2, part 3 of this article.
} 


\section{Some international comparisons}

More generally, these three seminars are representative of a more global tendency worldwide in the 1960s developments in economics of the firm and of industries. Three comparative examples could be given here. In Sweden first, the importance for academics to understand real business problems is a characteristic of the post-war period. In 1962, while recruiting a chair in managerial economics, Ulf af Trolle, professor at Lund University, regretted that "the tendency [he had] noticed to construct ideas about the commercial life from the depths of our minds, instead of going out and seeing what things actually look like" (Engwall, 2009, p. 89). Interestingly, this desire towards more empirical studies in business administration and managerial economics was balanced by the importance of theoretical foundations, when Sune Carlson, another senior scholar at Lund, established selection criteria of recruitment that included "1) a command of microeconomic theory in the applicant's particular field, 2) an understanding of microeconomic theory in relation to the setting within which firms work, 3) evidence of good knowledge of the internal and external data available for the scientific illustration of business administration problems"[Engwall, 2009, p. 90, italics added].

These 1960s initiatives towards empirical realism also took place in German's approaches to economics of firms and business administration which enabled students and future managers to acquire specialist competences - seen as foundations of the German alternative to American managerialism in the governance of firms (Locke, 1989). The training of business economists and more indirectly the orientation taken by equivalent research in the field was strongly criticised, since it was claimed that "business economists [were] obviously not willing to measure the achievement of their discipline in terms of innovative, convincing solutions and methods developed for practical problems. Instead, everything has to serve an abstract academic ideal (Dichgans, 1965, pp. 70-1, in Kipping, 1998, p. 98, italics added). In this context, the Baden-Baden 
seminars organised in 1951-1952 sought to contribute to this cause, yet organizing this dialogue outside the University and with the help of the Federation of German Industry, unlike the three seminars discussed in the context of this article.

In the US, while there was a long tradition of case studies-based methods initiated by Harvard University, dialogues took rather place between businessmen rather than between academics and businessmen. This is exemplified by the organization of short Industrial Management Seminars where American managers acquainted large groups of businessmen with the latest managerial know-how from the United-States (Kipping and Nioche, 1997). Yet, because of the debate developed below between the Chicago and the Harvard traditions, the American context did not leave much room for such dialogues. Nevertheless, it is worth noting that these British initiatives had been imported to some American Universities. The archives evidence, for instance, the organization of a graduate seminar in Economics of Industries "on the same lines as the Oxford Graduate Seminar in the same subject”, but with American businessmen in Winter 1963 (Andrews, 1963, p. 1).

\section{An illustration of the seminars' evolution: A text analysis of the Oxford B.Phil.}

\section{seminar's papers}

To illustrate the evolution of the seminars, one might be interested to zoom in the evolution of seminars' papers in the Oxford Seminar in Economics of Industries between 1956 and 1974. The list of all Oxford seminars that are accessible in the archives at the Bodleian and that were kindly given to us by Prof. David Stout - after having scanned them - were imported in Atlas.Ti and are reproduced in Table 1 (see appendix). Overall, this data set consists of a list of 76 seminars titles between Michaelmas Term 1956 and Michaelmas Term 1974, noting that the archives do not include any between 1969 and 1973. These titles have been complemented by the content of 14 scanned papers (out of 
the 76 titles) of approximately 10 pages each written by some participants to the seminars. These archives are scattered and incomplete, which makes difficult to conduct a systematic qualitative analysis. Yet, given these restrictions, the results of the text analysis are twofold.

First, regarding the contents of the papers accessible and that cover the period 1958-1966. Terms' occurrences clearly show the conceptual orientation taken by the Oxford seminar. The development of a theory of the firm which was either absent or a part of the theory of value in earlier economic theories has now been clearly developed. The term "firms" or "firm" is ranked first among economic concepts occurring in the documents. Interestingly, while the term "firms" or "firm" occur 291 times over the 14 seminars papers; the term "producers" or "producer" only appear 20 times while "supplier" or "suppliers" just appear 2 times. This strongly supports the idea that this new approach to the firm consisted of a shift in economic analysis, since it moved away from both marginal cost and rational choice theories in which the only account of a firm was a representative producer. The significance of the analysis of "costs" is also materialised by its second rank of occurrence. The high occurrence of the term "growth" shows the importance to discuss a dynamic understanding of the firm, outside the static view developed by earlier economic theories, in which size was preferred to growth.

\section{[Insert Table 2 here]}

Interestingly, these significant occurrences exist in contrast with some less cited economic concepts such as "theory" only used 25 times overall and "marginal" only used 29 times. On the period, the evolution of the use of these recurrent terms is not significant enough to be discussed here and to show a disappearance or an emergence of terms.

Still, while comparing the terms used in the 76 titles of the seminars, we introduce two 
main codes in which we gather several terms that indicate the desire to inject empirical realism in economic analysis: "industrial case studies" (including for example topics such as "shoe industry", "oil transport", "retail trade", etc.) and "practical economic concepts" (including for example concepts such as "workable competition" and "empirical costfunctions"). Results are exposed here.

\section{[Insert Graph 1 here]}

What the analysis shows is a decrease of both categories between 1956 and 1974, and more importantly the absence of any industrial case studies from 1962 onwards. As shown in Table 2, the term "game theory" appears for the first time in 1974, after Andrews left Oxford in 1968 and while chaired by Derek Morris.

\section{Causes of decline and emergence of new problems}

By the mid-1970s, these seminars ceased to exist. It is not relevant to look for critical arguments and controversies inside the seminars. This is due to two main factors. First, except in the Oxford case, the chairman has always been the same scholar (R. Edwards at the LSE, PS. Florence and L. Minkes at Birmingham). Consequently, to a large extent, genuine controversies did not take place. Within the seminars, there was no real room for the development of alternative approaches, as people invited were from the same vein as the organizers. Even the books which have been published as a result of these seminars are co-authored by their chairmen, respectively.

Yet, we provide four main alternative causes that could explain this interruption. Some are concerned with internal causes (due to chairmen's lives and institutional academic environment); while others result from external changes, in particular the diffusion of game theory as well as the developments of neo-liberal economic policies.

Internal causes due to individual factors related to the chairmen's lives and careers and 
their academic environment - There are first personality reasons and career explanations which are inherent to the specific institutional context in which each seminar took place. For instance, in Oxford, Andrews' and Brunner's attitude - which combined ahistorical empirically-oriented studies based on questionnaires addressed to contemporary businessmen with an explicit rejection of any collaboration with scholars invested in Oxford business studies - did not help to defend the initial tradition initiated by the OERG outside the traditional frame of perfect versus imperfect competition. In Birmingham, Leonard Minkes moved away from the organization of the Industrial Seminar when helped settling management education with the opening of the Graduate Centre for Management Studies (1966). To a large extent, these reasons for decline look similar to the case of Harvard and what Lazonick (1998) called "the neo-classical vision of the market and the firm" which resulted from the inability of Harvard economists and economic historians trained in the Schumpeterian tradition to develop a complete alternative view. The Harvard example has some parallels with these cases since as Lazonick noted, the old guard of the non-mainstream scholarship "exited to spend their time in administrative positions, research institutes, or professional schools" (Ibid.: 290). To a large extent, Andrews' and Brunner's move to Lancaster echoes Lazonick's contention that the "exit" of scholars who could have had a voice at Harvard played a role in the emergent dominance of more mainstream theoretical contributions. These three seminars" dying-out could therefore be interpreted as "failure of intellectual influence" rather than "a failure of intellectual achievement" (Lazonick, 1998: 291). No doubt that the interruption of the three seminars also resulted from an absence of potential successors to the initial chairmen. It would be worth noting, that in both Oxford and LSE, these seminars were at the periphery of other scientific activities led in the economics department. Andrews' tense relationship with Hicks made him rather marginal and might 
explain his departure to Lancaster. At the LSE, Edwards' group was marginalised by Robbin's department which was seen as more theoretical and rigorous, as it gathered Hayek and Kaldor.

External causes due to the emergence and the diffusion of game theory in the field of industrial organization, especially in the US

To put things in a nutshell, the emergence of game theory is a post WWII American development based on the formal construction and diffusion of tools applied to economic analysis (see in particular the successive contributions of Von Neumann and Morgenstern, Nash, Selten, Harsanyi and Aumann). This first period of emergence was followed by a second period at the beginning of the 1970s-game theory was imported to economic theory, which led to new advances in the field of industrial organization. Giocoli (2008) refers to the famous controversy between the Chicago and the Harvard traditions. At the time, game theorists brought new perspectives and changed the nature of the main developments mainly encapsulated in imperfect competition, that founded until then, both Harvard and Chicago traditions. This intrusion of game theory in economic theory was soon to appear in France (Arena, Dutraive, 2016), as well as in the UK.

In particular, the import of game theory initiated in the US in British economics of industries and business administration is exemplified, when one compares the successive editions of the landmark textbook on industrial economics first published in 1979 by Hay and Morris. The textbook served as a basis for teaching even decades after its publication all around Europe. The first edition aimed at defining industrial economics as a subject, emphasising disagreements on both theoretical and empirical issues and the confusion over the scope, concepts and methodology in the field. While Hay and Morris' approach to firms and industries rejected standard economic theory; their contribution to the subject 
still constituted a break away from the Oxford empirical tradition, as shaped by the Seminar in Economics of Industries. This judgment is reinforced by comparing the first edition (1979) with the second edition, published in 1991, under a slightly different title (Industrial Economics and Organisation - Theory and Evidence). The first edition of Industrial Economics - Theory and Evidence referred only twice to Andrews' normal cost theory. As regards Marshall, Hay and Morris adopted a very cautious approach, their references to him being limited to their historical introduction to the textbook. They argued that Post-Marshallians have lost a part of Marshall's message in dedicating too much work to purely empirical studies. The main difference between the first and the second editions lies in the ebbing of controversy within the field of industrial organization between 1979 and 1991, mainly because of the increasing domination of game theory in the theory of imperfect competition and strategic interaction. Interestingly, the change in title between the two successive editions did not merit comment or explanation from the authors. However, the second edition indicated a shift away from empirical studies towards formalization, which had initially emerged in the United States.

Causes due to the rise of neo-liberal approaches and the emergence of business studies in the $U K$

On a different front, the 1970s are often associated with the emergence of neo-liberalism, resulting from the elections of R. Reagan in the US and M. Thatcher in the UK. Characteristics of this emergence have been largely studied elsewhere (Harvey, 2007) and do not need to be recounted here, since neo-liberalism per se did not exert a direct analytical influence on the death of our three seminars. Yet, economic policy debates that followed this emergence were particularly concerned with competition policies. Hence, this directly impacted the orientation of industrial organization, which dealt less and less with business behaviours and practices in a specific industry and increasingly on the 
nature of national industrial policies, especially at an inter-industrial level. As a result, the diffusion of neo-liberal policies indirectly fostered the methodological and conceptual orientation of industrial organization that gradually moved away from the forms of thought initiated in the Oxford and LSE seminars. The development of business studies also contributed to this decline.

The study of firms and industries based on the collection of business and industrial facts, as conducted in the three seminars, soon became the topic of a separate academic discipline which first emerged in the 1960s and became increasingly prevalent in the UK from the 1970s onwards. The need to implement business studies and to import management education from the US was strongly influenced by the American graduate schools of business administration. These developments sparked off a controversy over the legitimacy of university involvement in management education and led the whole subject to become a matter for public debate. An increasing number of British businessmen gathered to establish the Foundation for Management Education (FME) ${ }^{14}$. Far from impressed by the FME's developments, some other industrialists, met informally at the Savoy Hotel in London to work on the creation of a "British Harvard"15 calling themselves the Savoy Group (Whitley, Thomas, Marceau, 1981: 44). These

${ }^{14}$ The FME financed the establishment of London and Manchester Business School, a few years later. The FME still exists and seeks to encourage business leaders to make the transition between the private sector and business school academia. For further details on this institution: http://management-education.org.uk

${ }^{15}$ The members of the Savoy Group differed from the FME's work, mainly because their main idea was in favour of the need for a "completely new type of college which would be tailormade to fit industry's requirements', created independently from any existing structures (Whitley, Thomas, Marceau, 1981: 44). 
establishments were soon followed by the creation in 1961 of the National Economic Development Council (NEDC) to reconcile trade-unions, industry, and government, as a response to England's economic and social decline (Locke, 1996: 46). Two years after its creation, this Council reported the need for "at least one very high-level new school or institute, along the lines of the Harvard Business School, or the School of Industrial Management at the Massachusetts Institute of Technology" (NEDC report, 1963: 5-6). From this conclusion, the FME, the Savoy Group and the NEDC appointed a Committee, led by Lord Franks, which sought to provide detailed recommendations about the implementation of these new schools of business in the UK. Lord Franks' enquiry was made easier by the conclusions drawn from the Robbins report a month earlier, which suggested that "two major post-graduate schools should be built up in addition to other developments already probable in universities and other institutions" (Robbins, 1963: 65).

Whereas the Edwards' seminar was probably less concerned with this cause, the decline of the Oxford and the Birmingham ones are clearly impacted by this trend. While in Oxford, business studies had to undergo a long drawn-out process of negotiation, it is as late as the early 1960 s that the first courses in management can be found. Rather than any explicit choices by its administrative and academic office, what was instrumental to this initial resistance to management studies as a separate discipline, was a combination of the university's overall elitist and traditional outlook, anxieties about infringing on traditional disciplinary boundaries and skepticism about business studies in particular. Yet, the emergence of business studies in Oxford was not unfamiliar with the dialogue method initiated by Andrews' industrial economics. The B.Phil. in management studies ran for the first time in 1967 , after many years of discussions and negotiations among the different members of the Economics Faculty (Arena, 2010). A controversy emerged 
between, on the one hand, Norman Leyland - main instigator of the project, who was in favour of a combination of industrial economics and business studies - and Philip Andrews, on the other, who refused to be associated with this new discipline. The $24^{\text {th }}$ January 1966, Philip Andrews, Elizabeth Brunner, David Stout and Lady Margaret Hall jointly commented on the 'proposed use of the economics B.Phil. paper in economics of industries in the management studies B.Phil ${ }^{16}$. The authors of these comments suggested that:

“[...] the paper [in Economics of Industry] as at present taught is not likely to be a suitable regular option for management studies candidates, and that to cater for an extension of its use in that way would be likely to damage the work at present being done in the existing seminar".

They provided different reasons supporting this idea ${ }^{17}$. If we exclude personal reasons mainly concerned with the poor quality of the relationship between Andrews and Leyland at the time, alternative explanations of this strong protest about including the economics of industry paper in the B.Phil. in management studies can be drawn. Andrews made clear on several occasions in his correspondence that he was not opposed to the development

\footnotetext{
${ }^{16}$ Andrews and Brunner's archives, LSE, Box 258.

${ }^{17}$ For instance, lack of knowledge in economics from students in Management Studies ("The membership has generally included only men of fairly good quality as economists"), confidence issues with businessmen which could arise from the introduction of new people, general incompatibility between the aims of the B.Phil. in Management Studies and the purpose of the Seminar, library related issues, and so on.
} 
of management studies in Oxford ${ }^{18}$. Still, his arguments could be analysed as real fear regarding the future orientation of industrial economics in Oxford. When, seven years before, Elizabeth Brunner described the birth of industrial economics in Oxford, she already stressed the risk for industrial economics to be confused with management studies:

"Let us hope that the name [of Industrial Economics] does not become too popular and dwindle into a synonym for Management Studies" (Brunner, 1961).

In Birmingham, Leonard Minkes was elected Professor in 1972 and got the Chair in Business Organization. He then became a leading individual in Birmingham and helped settling management education with the opening of the Graduate Centre for Management Studies (1966). which was a joint enterprise of the Universities of Birmingham and Aston and which was considered only as an episode since it lasted for approximately eight years before leading to two separate business schools (Minkes, 2011(b)). When this venture was terminated, Minkes went back to the Faculty of Commerce and Social Science at Birmingham and became Dean for the normal 3-year period, which made impossible to keep running the seminars. To our knowledge, nothing similar was done at Aston. To Minkes, at the time, the seminar method could be regarded intellectually as forerunner in the development of University Schools of business.

\section{Conclusion}

Overall, this contribution does not claim that the seminar method was the sole means of empirical study - nor that empiricism or empirical realism is the only road to understanding. Yet, the three seminars described in this article shared the particularity

18 “"...] But that does not mean that I am to be treated as a person hostile to management education." (Ibid: 4). 
to develop a then novel form of dialog with businessmen which never emerged before in economics. Nevertheless, the three seminars did not assign the same status to empirical facts and to dialog with industrialists in their process of production of knowledge. Overall, while the Seminar in Problems of Administration (LSE) and the Industrial Seminar (Birmingham) aimed at providing a better understanding of "actual operations of firms and industries" in the first case and of "business behaviour" in the second, the Graduate Seminar in Economics of Industry used dialogue and facts to provide theory-testing and to challenge traditional theories of the firm. Then, the first two seminars strongly shared the desire to bridge the gap between economic theory and economic facts. As shown earlier, the Birmingham Industrial Seminar was narrower in terms of topics, as it essentially targeted behavioural and organisational theories of the firm and was largely interested to draw "critical reality" to current theoretical considerations in decision-making analysis.

The interruption of this seminar (dialogue) method resulted from the evolution of economic thought and methodology at the time. As shown in this paper, the context of thought in which these seminars evolved was a transitional period of analytical uncertainty between two periods of 'high theory': 1. the Marshallian legacy encapsulated in the 'cost controversies' debates in Cambridge which lasted between the mid-1920s and the beginning of the 1930s and 2. the emergence of systematic applications of game theory to industrial organisation mainly in the US by the critics addressed to the general equilibrium research program (see the so-called "DMS (Debreu-Mantel-Sonnenschein) theorem" in the 1970s). This contribution showed that the method of research used in the seminars echoes a) a difficulty for academics to use standard economic theory, since they believed that earlier theories were not fitted to the study of industrial structure and business practices; b) a difficulty for academics to 
produce an alternative integrative research program in a situation where, to use SylosLabini 's own terms, microeconomic theory was in a "fluid, not to say, chaotic state" (Sylos-Labini, 1962). Although it would be misleading to stress a homogenous and coordinated research program between these three seminars for the reasons we already stressed. Prevalently, methodological discussion did not exclude however debates related to the emergence and the meaning of some analytical concepts in each respective academic community. 


\section{References}

Andrews P.W.S., "Preliminary notes on the University of Pittsburgh Graduate Seminar in Economics of Industries" - Box 258, Andrews and Brunner's Archives (LSE), 1963.

Andrews P.W.S., “Letter to David Liston, The Metal Box Company, 10/01/1957”, Box 529, Andrews and Brunner's archives (LSE), 1957.

Ansoff, I.H. Corporate Strategy - An Analytical Approach to Business Policy for Growth and Expansion, McGraw-Hill Inc., 1965.

Arena, L. "The Evolution of Labour Welfare after the Birth of Scientific Management: 'Economics of Fatigue and Unrest' Revisited”, History of Economic Ideas, 22, $\mathrm{n}^{\circ} 1$ (2014): 85-110.

Arena L. "The Marshallian Tradition of Industrial Economics in Oxford (1947-1979): From Andrews' Contribution to the Emergence of Industrial Organization and Business Studies", in T. Raffaelli, T. Nishizawa and S. Cook, Marshall and Marshallians on Industrial Economics, Routledge, 2010.

Arena, R. and V. Dutraive. "La théorie des jeux peut-elle aider à comprendre l'évolution des politiques de la concurrence et des politiques industrielles depuis la fin des années 1970?", Revue économique, , vol. 67, (2016) : 9-24.

Brunner, E. "The Training of Academic Industrial Economists", Talk to Frank Friday Group, (not dated but estimated in 1961) - Box 529, Andrews and Brunner's Archives (LSE), 1961.

(Philip W.) Andrews and Elizabeth Brunner's archives, London School of Economics.

Cary, J. An Essay on the State of England: In Relation to Its Trade, Its Poor, and Its Taxes, for Carrying on the Present War Against France, W. Bonny: Bristol, 1695. 
Clapham, J.H. "Of Empty Economic Boxes”, Economic Journal, 32, n¹27, (1922): $305-314$.

Coase, R.H. Essays on Economics and Economists, University of Chicago Press, 1994.

(Ronald) Edwards’ Archives, London School of Economics.

Edwards, R.S. and D. Black. "Notes on the British Income Tax and Company Reserves", The Review of Economic Studies, 5, n², (1938): 114-122.

Edwards, R.S. "The Rationale of Cost Accounting" in Plant A. (Eds.), Some Modern Business Problems, Longmans, Green and Co., Ltd., 1937.

Edwards, R.S. and H. Townsend. Business Enterprise: Its Growth and Organisation, Macmillan, 1958.

Edwards R.S. and H. Townsend. Studies in Business Organisation: A Supplement to 'Business Enterprise’, Macmillan, 1967.

Giocoli N. "Three alternative (?) stories on the late 20th-century rise of game theory", Munich Personal Repec Archive, (2008).

Harvey D. A Brief History of Neoliberalism, Oxford University Press, 2007.

Kipping M., "The Hidden Business Schools: Management Training in Germany since 1945”, in Engwall L. and Zamagni V. (Eds.), Management Education in Historical Perspective, Manchester University Press, (1998): 95-107.

Kipping M. and J.P. Nioche. "Politique de productivité et formations à la gestion en France (1945-1960): Un essai non transformé”, Entreprises et Histoire, Vol. 14, (1997) : $75-96$. 
Lazonick, W. "What Happened to the Theory of Economic Development", in Higgonet, Landes, Rosovsky, (Eds.), Favorites of Fortune: Technology, Growth and Economic Development since the Industrial Revolution, Harvard University Press, (1998): 267-296.

Locke, R.R., The Collapse of the American Management Mystique, Oxford University Press, 1989.

Marshall, A, The Present Position of Economics. An Inaugural Lecture Given in the Senate House at Cambridge: $24^{\text {th }}$ February 1885, London: Macmillan, 1885.

Marshall, A. The New Cambridge Curriculum in Economics and Associated Branches of Political Science; Its Purpose and Plan, London: Macmillan, 1903.

Minkes, A.L. "Philip Sargant Florence - An Economist Sociologist" in Raffaelli T., Minkes, A.L. "Early Years in University Development in Management Education: reflections and Reminiscences on the University of Birmingham (1950s-1970s)", Entreprises et Histoire, 65, $\mathrm{n}^{\circ} 4,(2011(\mathrm{~b})):$ 83-95.

Minkes, A.L. "Business and a Behavioural Tradition - An Inaugural Lecture delivered in the University of Birmingham on 21 November 1972", Published by the University of Birmingham, 1972.

Minkes, A.L. and C.S. Nuttall. Business Behaviour and Management Structure, Billing \& Sons Limited, 1985

Petty, W. A Treatise of Taxes and Contributions shewing the Nature of Measures of Crown Lands, Assessements, Customs, Poll-Money, Lotteries, Benevolence, Penalties, Monopolies [...], Printed for N. Brooke at the Angel in Cornhill, London, 1662.

Pigou, A.C. The Economics of Welfare, London: MacMillan, 1920. 
Pigou, A. C. and D.H. Robertson. “Those Empty Boxes”, Economic Journal, 34, n¹33, (1924): 16-31.

Sargant Florence, P. Economics and Human Behaviour: A Reply to Social Psychologists, W.W. Norton Incorporated, 1927.

Sylos-Labini P. Oligopoly and Technical Progress, Harvard University Press, 1962.

Whitaker, J.K. "Alfred Marshall: The Years 1877 to 1885", History of Political Economy, 4, n¹, (1972): 1-61.

Worswick, G.D.N. “Drummond Professor of Political Economy, 1945-51”, Oxford Economic Papers, New Series, Vol. 5, Supplement: Sir Hubert Henderson 1890-1952, (1953) : 65-79. 